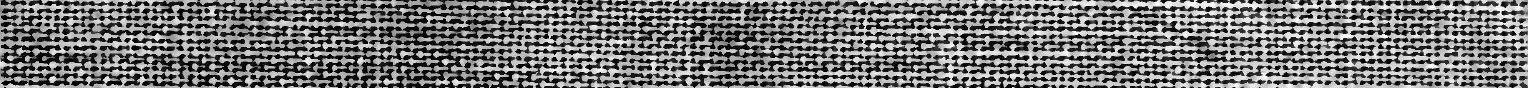

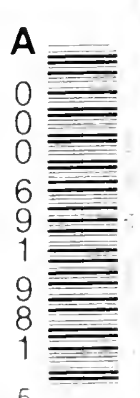

西,

(1)

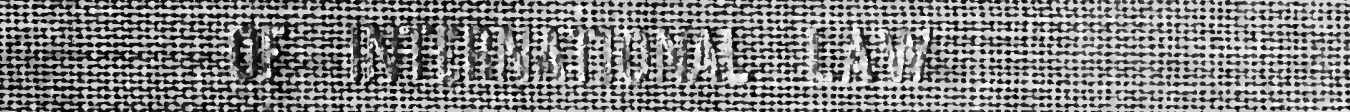

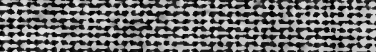
ton
tivitive

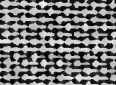

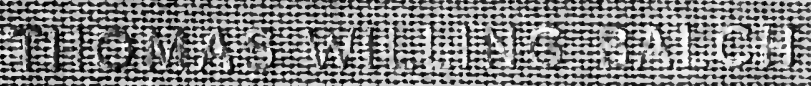

Pot

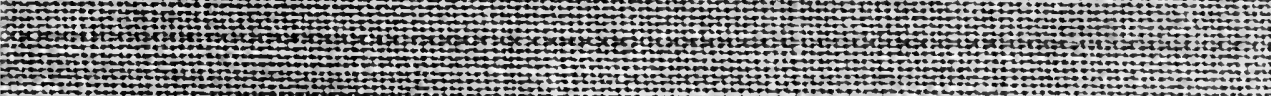

$\operatorname{tin}^{20}$

(1) W

OX

W

for

W

W

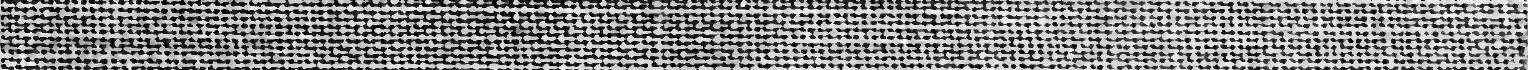

Now

L t

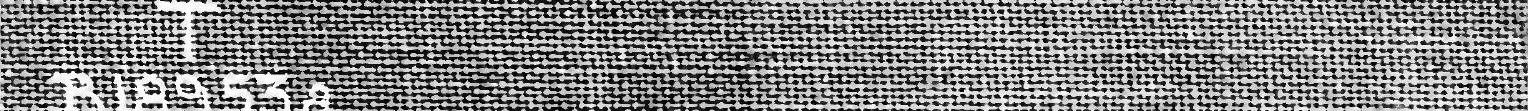




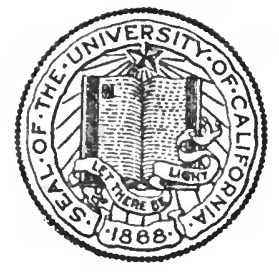

\section{UNIVERSITY \\ OF CALIFORNIA \\ LOS ANGELES}

SCHOOL OF LAW

LIBRARY 


\section{Digitized by the Internet Archive in 2007 with funding from Microsoft Corporation}



$$
\text { , }
$$

$$
\bullet
$$


“ARBITRATION" AS A TERM OF INTERNATIONAL LAW 


\section{WORKS BY THE AUTHOR.}

Some facts about Alsace and Lorraine, I 895.

The Brooke Family of Whitchurch, Hampshire, England, together with an account of Acting-Governor Robert Brooke of Maryland and Colonel Ninian Beall of Maryland, I899. The Alabama Arbitration, 1900.

Emeric Crucé, Igoo.

The Alasko-Canadian Frontier, 1902.

The Alaska Frontier, I903.

The English Ancestors of the Shippens and Edward Shippen of Philadelphia, I904.

The Swift Family of Philadelphia, I 906.

Balch Genealogica, I907.

L'Évolution de l'Arbitrage International, I 908.

La Baie d'Hudson, est elle une mer libre ou une mer fermée, I9II?

La Baie d'Hudson est une grande mer ouverte, I9I3.

Différends juridiques et politiques dans les rapports des Nations, I9I4.

The Influence of the United States on the Development of the Law between Nations, I9 5 .

Legal and Political International Questions and the Recurrence of War, I9i6.

The Philadelphia Assemblies, r9r6.

A World Court in the light of the United States Supreme Court, i9i8. 


\title{
“ARBITRATION" AS A TERM OF INTERNATIONAL LAW
}

\author{
BX \\ THOMAS WILLING BALCH \\ L. H. D. Trinity College (Hartford) \\ Member of the Philadelphia Bar \\ A Vice-President of the Historical Society of Pennsylvania
}

REPRINTED FROM THE COLUMBIA LAW REVIEW NOVEMBER AND DECEMBER, 1915

\section{Philadelphia}

ALLEN, LANE AND SCOTT

1920 
$T$

B $18953 a$
1920

334660

10.4 .60

n. R.th 
MY FRIEND

JOHN BASSETT MOORE

A MASTER OF THE SCIENCE OF INTERNATIONAL LAW 


\section{PRELIMINARY NOTE.}

This essay was originally published in The Columbia Law Review in the numbers of November and December, 1915. It is now reprinted with the kind permission of the editor of The Review.

Philadelphia, June I5Th, 1920. 



\section{"ARBITRATION" AS A TERM OF INTER-' NATIONAL LAW.}

In spite of the breaking out of The Great War, involving in its meshes more than half of the land on the earth and the majority of the great powers of the world as well as many small ones, at present (May, 1915) ten in all, nevertheless ample proof is to be found in the historic development of International Arbitration, especially within the past fifty years, as a mechanism for settling differences between nations by judicial means, that, thanks to the establishment of the International Courts which sat upon the Alabama Claims and the Bering Sea Fur Seal Fisheries cases respectively, a precious instrument to avoid war in many instances beyond the scope of diplomatic negotiations to settle, has been evolved in the institution known as International Arbitration. Unfortunately, of late years, a tendency has arisen to confound International Arbitration with Municipal Arbitration and, to minimize if not indeed to deny entirely the judicial quality of arbitration as a component part of the Law between Nations. Doubtless this confusion in the thoughts of those 
who have not studied attentively the philosophical development of the Law between Nations is largely due to a failure to realize that the word Arbitration has come to have different meanings according as it is used in Municipal Law on the one hand and International Law on the other. It seems, therefore, well worth while to examine the meaning of the word arbitration, as it has been defined in the older dictionaries of the English language, both in England and America, together with the meaning of the word mediation. Then to test the sense and meaning of the word arbitration as used by some of the undoubted masters of the science of the Law between Nations. And finally compare the judgments given by the Geneva and Paris International Tribunals in the Alabama Claims and the Bering Sea Fur Seal cases respectively, with some decisions rendered by some notable Municipal Courts. In that way a just opinion as to what was intended by the men who thought out and developed the institution of International Arbitration could be formed.

First of all let us see what meaning the earlier English lexicographers have assigned to the word arbitration and then what sense the earlier American lexicographers have given to the same word. 
In the fourth edition of Edward Phillipps's well known dictionary, The New World of Words, published at London in 1678 by himself, he merely says:

"Arbitrator (Lat.) An umpire, a commissioner, chosen by mutual consent to decide controversies between party and party."

In his fifth edition printed in 1696 , he says:

"Arbitrator, (Lat.) An umpire, a commissioner, chosen by mutual consent to decide controversies between party and party."

"Arbitrament, An award, Determination, or Judgment which one or more make at the request of two or more parties upon some Debt, Trespass, or other Controversie."

In the seventh edition of $1720,{ }^{1}$ much more is given in reference to the general subject of arbitration, as follows:

"Arbiter, an Arbitrator, an Umpire, a Sovereign Disposer. See Arbitrator.

"Arbitrage, an Arbitrator's or Umpire's Decree or Sentence.

"To arbitrate, to award, give Sentence, adjudge, or act as an Arbitrator.

"Arbitration, the Act of Arbitrating, the Putting

${ }^{1}$ The New World of Words, or Universal English Diclionary, compiled by Edward Phillipps, Gent. Seventh edition, London, I 720. 
an End to a Difference by the Means of Arbitrators.

"Arbitrator, an extraordinary Judge, indifferently chosen by the mutual Consent of two Parties, to decide any Controversy between them; a Days-Man or Referee: The Civilians make a difference between Arbiter and Arbitrator; the former being obliged to proceed according to Law and Equity; whereas the latter is left wholly to his own Discretion, to act without Solemnity of Process, or Course of Judgment."

Thus Phillipps, while at first he does not define very precisely what an arbitrator is, gradually in his succeeding editions leans more and more to the view that an arbitrator is a judge and his decisions are judgments. Again Phillipps, in his fifth edition, speaks of arbitrament as being a judgment. In his seventh edition of 1720 , the judicial quality of arbitration, using the word in a generic sense, is much more marked and clearly stated. Thus "to arbitrate" is said in that edition, among other definitions, to mean to "give sentence," and "to adjudge." And the word "arbitrator" is defined as meaning "an extraordinary judge."

In the latter part of the eighteenth century, Samuel Johnson, who surely was a man of letters 
possessed of no small knowledge of the meaning of his native English tongue, supports in his Dictionary much more strongly and exactly than his predecessor Phillipps the judicial character of arbitration. For example, in the fourth edition of his celebrated Dictionary published in $1773,{ }^{2}$ he says:

"An Arbiter, n. f. (Lat.)

"I. A judge appointed by the parties, to whose determination they voluntarily submit.

"2. One who has the power of decision or regulation; a judge.

"To Arbitrate, v. a. (arbitror, Lat.)

"I. To decide; to determine.

"2. To judge of.

"To Arbitrate, v. n.

"To give judgment.

"Arbitration, n. f. (from arbitror, Lat.)

"The determination of a cause by a judge mutually agreed on by the parties contending.

"Arbitrator, n. f. (from arbitrate).

"I. An extraordinary judge between party and party, chosen by their mutual consent.

"Arbitrement, n. f., (from arbitror, Lat.)

"I. Decision; determination.

${ }^{2}$ Samuel Johnson, Dictionary of the English Language: fourth edition, revised by the Author, London, I773. 
"2. Compromise."

Thus Johnson speaks of an arbiter as a "judge." To arbitrate he defines as "to decide" and "to judge of." "Arbitration" he says is the settling of a question by "a judge mutually agreed on" by the disputants. In the end he defines the word "arbitrament" equally as meaning a decision and a compromise, two distinctly opposite terms. But excepting this last definition which is one half in favor of supporting the idea that the group of words described by the generic term "arbitration" means an adjustment of a dispute upon the basis of give and take by the disputants, Johnson strongly supports the view that in his time the word "arbitration" meant the settlement of a controversy by a judge chosen by the parties concerned to decide that one specific case.

Johnson's support of the judicial meaning of the word arbitration in his time is further attested by his clear definitions of the group of words that may be classified under the generic word mediation. In the edition of 1773 , Johnson says:

"To mediate, v. n. (from medius, Latin.)

"I. To interpose as an equal friend to both parties; to act indifferently between contending parties; to intercede. 
"2. To be between two.

"Mediation, n. f. (mediation, French; from medius, Lat.)

"I. Interposition; intervention; agency between two parties, practised by a common friend.

"2. Agency interposed; intervenient power.

“3. Intercession; entreaty for another.

"Mediator, n. f. (mediateur, French.)

"I. One that intervenes between two parties.

"2. An intercessor; an entreator for another; one who uses his influence in favor of another.

"3. One of the characters of our blessed Saviour."

Thus mediation, according to Johnson's Dictionary, clearly means an attempt to have a diffculty arranged by the friendly advice of a third party.

If we turn next to American lexicographers we find that Noah Webster, in the first edition of his well known Dictionary, ${ }^{3}$ says:

"Arbitrate, v., to hear and judge as an arbitrator.

"Arbitration, n., reference of a controversy to persons chosen by the parties, a hearing before arbitrators, award.

"Arbitrator, n., a person chosen by a party to

${ }^{8}$ Noah Webster, A Compendious Dictionary of the English Language, New Haven, I806. 
decide a controversy, one who has the sovereign right to judge and control."

"Mediate, v., to endeavor to reconcile, to limit.

"Mediation, n., an interposition, agency, entreaty.

"Mediator, n., an intercessor, kind adviser, manager."

A comparison of the above two groups of words, as defined by Webster makes it clear that in Webster's judgment when he published his first dictionary in I806, an arbitrator's function was to judge, while that of a mediator was to adjust a dispute. He does not say one word to suggest that arbitration means a compromise even in a remote degree.

In the I84I edition of Webster, a great deal more is said about both groups of words. In speaking of an arbiter or arbitrator and of arbitration, except that twice he says that an arbiter or arbitrator has the power of judging or deciding "without control," Webster still describes an arbiter or arbitrator as a judge chosen for a certain specific case, in other words a judge chosen ad hoc. For to Arbitrate he says, in 1841, means "to decide; to determine; to judge of." Mediation and Mediator and their kindred words, he defines as synonymous with reconciliation or adjustment. 
While Webster does not support as clearly as some of the earlier English lexicographers do the judicial character of an arbitrator and of arbitration, Worcester, the other great American lexicographer, emphatically does. In his edition of $1846^{4}$ Worcester says:

"Arbiter, n. (L.) One appointed to decide a point in dispute, an arbitrator, a judge.

"Arbiter, v. a. To judge.

"Arbitrate, v. a. (i. arbitrated; pp. arbitrating, arbitrated.) To decide; to judge of.

"Arbitrate, v. n. To give judgment. South.

"Arbitration, n. Act of Arbitrating. (Law.) The investigation and determination of a cause by an unofficial person, or by persons mutually chosen by the contending parties; arbitrament.

"Arbitration, Bond. n. (Law.) A solemn obligation to submit to an award. Blackstone.

"Arbitrator, n. An umpire; a judge. (Law.) A person chosen by parties at variance to determine a matter in dispute."

"Mediate, v. n. (medius, L.) (i. mediated; pp. mediating, mediated.) To interpose, as a common friend, between two parties, to intercede; to be between two.

${ }^{4}$ Joseph E. Worcester, Dictionary of the English Language, Boston, I 846 . 
"Mediate, a. (médiat, Fr.) Intervening; middle; be between two extremes.

"Mediation, n. (Fr.) The act of mediating; interposition, intervention, agency interposed; intercession.

"Mediator, n. (mediator, L.; mediateur, Fr.) One who mediates; an intercessor; one of the characters of our blessed Saviour."

In the above definition of those two groups of words, Worcester says of an arbiter that he is "a judge," and to arbitrate is "to decide; to judge of," while an arbitrator he maintains is "a judge." In that group he says nothing of reconciliation or anything else that suggests in the remotest degree compromise. But in the group of words relating to mediation, he does distinctly maintain that they mean reconciliation. A comparison of the two groups of words makes it still more clear that in Worcester's estimation an arbitrator was a judge chosen for the occasion.

If one turns from these two renowned American lexicographers to the Law Dictionary of John Bouvier, one finds that in his second edition of $1843,{ }^{5}$ he maintains that an arbitrator is a judge.

\footnotetext{
5 John Bouvier, A Law Dictionary, second edition, Philadelphia, I 843 .
} 
Bouvier says:

"Arbitrator:-A private extraordinary judge chosen by the parties who have a matter in dispute, invested with power to decide the same. Arbitrators are so called because they have generally an arbitrary power, there being in common no appeal from their sentences, which are called awards."

When he defines mediation, however, he says that it means compromise.

"Mediation, is the act of some mutual friend of two contending parties, who brings them to agree, compromise or settle their disputes."

Thus in defining these two words Bouvier sharply defines the difference between them, to wit, that an arbitrator is to judge, while a mediator is to bring about an agreement by means of a compromise.

In the edition of $\mathbf{I} 894$ of this same work, ${ }^{6}$ there is this definition:

"Arbitrator. In Practice. A private extraordinary judge, to whose decision matters in controversy are referred by consent of the parties."

In the above definition the judicial character of an arbitrator is distinctly maintained.

'John Bouvier, A Law Dictionary, Philadelphia, 1894. 
In the edition of $1914,^{7}$ edited by Francis Rawle, we find:

"Arbiter: A person bound to decide according to the rules of law and equity, as distinguished from an arbitrator, who may proceed wholly at his own discretion, so that it be according to the judgment of a sound man."

Then the following illuminating statement is immediately made:

"This distinction between arbiters and arbitrators is not observed in modern law."

Continuing to define the word, arbiter, Bouvier's I9I4 edition says:

"One appointed by the Roman praetor to decide by the equity of the case, as distinguished from the judex, who followed the law."

"One chosen by the parties to decide the dispute; an arbitrator."

In this last edition of Bouvier nothing is said about an arbitrator being a reconciler.

After this review of some of the leading authorities in the meaning of words in English, it is evident that the words arbitrator and arbitration when used

${ }^{7}$ John Bouvier, Law Dictionary and Concise Encyclopedia, third revision, eighth edition, edited by Francis Rawle; Kansas City and St. Paul, I9r4. 
as terms of Municipal Law in the past meant something different from the boards of arbitration which, constituted to-day under Municipal Law to decide between corporations and their employees, often agree to recognize most of the demands of the latter regardless of any justice or equity applicable to the controversy. So that in the light of the masters of the meaning of English words, it is evident that the words arbitrator and arbitration as often used to-day in practice in our municipal relations have so largely changed their meanings of a half century and more since, that in municipal affairs to-day an arbitrator has in many instances almost entirely lost the judicial character that was designated by the same word in the middle of the last century and before that time. Nevertheless, the meaning attaching often to-day in Municipal Law to the words arbitrator and arbitration does not alter the fact that according to the best English and American lexicographers, those words in the past did mean that an arbitrator was a temporary judge and not a reconciler, and that when an arbitrator was appointed to hear a cause of difference between two parties, he was to decide the case as a judge and not to try to arrange it by a compromise. 
All these lexicographers, however, when they defined the words arbiter, arbitrator, arbitration and kindred words did not have in mind specifically the Law between Nations. Consequently, to find more authoritively the meaning of those words as terms of the Law between Nations, it will be necessary next to examine what some of the leading publicists have understood by the word arbitration and kindred words when used as terms of International Law. The value of the opinions of well known publicists as to what is the Law between Nations has been attested by eminent judges sitting in the highest courts in the world. Thus Sir William Scott, afterwards Lord Stowell, sitting in $\mathbf{I} 799$ in the High Court of Admiralty of England upon the case of the Maria, ${ }^{8}$ relied on the Swiss publicist, Vattel, "not as a lawyer merely delivering an opinion, but as a witness asserting the fact-the fact that such is the existing practice of modern Europe." And in 1900 in the case of the Paquete Habana, ${ }^{9}$ Justice Gray of the United States Supreme Court said of the Law between Nations and treatises on that Law:

"International Law is part of our Law, and must be ascertained and administered by the courts of

\footnotetext{
${ }^{8}$ (1799) I Christopher Robinson, pages $340,{ }^{*} 64$.

${ }^{9}$ (1900) I 75 United States Supreme Court Reports 677, 700.
} 
justice of appropriate jurisdiction, as often as questions of right depending upon it are duly presented for their determination. For this purpose, where there is no treaty, and no controlling executive or legislative act or judicial decisions, resort must be had to the customs and usages of civilized nations; and, as evidence of these, to the works of jurists and commentators, who by years of labor, research and experience, have made themselves peculiarly well acquainted with the subjects of which they treat. Such works are resorted to by judicial tribunals, not for the speculations of their authors concerning what the Law ought to be, but for trustworthy evidence of what the Law really is."

Among such publicists and jurists, first let us turn to Baron Puffendorf's treatise, Of the Law of Nature and Nations, ${ }^{10}$ originally published in 1672 . In discussing the means other than war of settling the differences that arise, he refers to arbitration, after other modes of settlement have failed, in these words: "The only thing they [the disputants] can do, is to pitch upon an Arbitrator, and each bind himself to stand to his Award."

Speaking of the qualifications necessary for an

${ }^{10}$ Samuel Puffendorf, Of the Law of Nature and Nations, Oxford I 7 I0. 
impartial arbitrator, Puffendorf says that no one must be chosen for such a position who has a reason that one side or the other shall win. Then concerning the way the arbitrator shall judge, Puffendorf says: $:^{11}$

"Now altho' the contending Parties enter into Compact with the Arbitrator, about taking upon him his Office, (for as no Arbitrage can be exercised without the Consent of the Parties, so no one can be forced to be Arbitrator against his own Consent;) yet it is not from the Force of that Compact, that he becomes obliged to judge according to what he thinks is agreeable to the Laws of Conscience and Equity: or they to stand to his Award. For the Law of Nature, which can receive no Enforcement from any Compact, obliges him to judge according to Justice; and they are obliged to submit, without any Reserve, to his Determination, because otherwise the Design of going to an Arbitrator would be frustrated, and there would be no End to such Appeals."

After discussing the question whether an arbitrator should judge according to the law, or whether he should mitigate its severity, Puffendorf says: ${ }^{12}$

11 S. Puffendorf, Of the Law of Nature and Nations, Oxford, I 710, page 435 .

${ }^{12} I d$., page 436 . 
"If it be doubtful under which of these two Qualifications the Arbitrator is chosen, he ought to suppose himself tyed up to those Rules, which a Judge would be obliged to follow; for it is for want of a Judge and Judicature that he is called in: And, in a doubtful case, we ought to take that side which is clearest. Besides, an Arbitrator can't so easily act unjustly, if he has a limit, as if he has an absolute Power delegated to him." Then Puffendorf makes a reference to mediation and the duties of a mediator in these words: "Indeed to persuade a Mitigation of the Rigour of the Law is properly their Business who voluntarily, without entring into any Engagements, interpose, as common Friends, between the contending Parties."

Then as to the kind of law that judges should use in judging, he says: "Now as he that judges between Fellow-subjects, judges according to the Municipal Laws of that Place; so he who judges between those who acknowledge no common Municipal Laws, ought to judge according to the Law of Nature; unless the Parties submit their Cause to the positive Laws of some particular State."

Many times Puffendorf speaks of the "judgment" of an arbitrator. He also says: "This Arbitrators have in Common with Judges, that, in the Examina- 
tion of Matters of Fact, they ought to shew themselves equal to the bare Asservation of each party, $i$. $e$. when they contradict one another, to believe neither. But when Deeds, Arguments and undeniable Instruments can't be produced, they must then give Judgment according to the Testimony of Witnesses.".

In the same chapter in which he treats of arbitrators and arbitration, Puffendorf also speaks of mediators whom he differentiates clearly from arbitrators as follows:

"But Mediators, who interpose between contending Nations, either preparing or actually engaged in War, and endeavour, by their Authority and their Arguments and Intreaties, to bring them to Terms of Accommodation are not properly Arbitrators."

Thus in Puffendorf's conception, if contending Nations appealed to an arbitrator, that arbitrator was to judge between them, while a mediator was to reconcile them by more or less of a compromise.

The Swiss, Emerich de Vattel, in the second half of the eighteenth century says: $:^{13}$

"The mediator ought to observe an exact impartiality; he should soften reproaches, calm resent-

${ }^{13}$ Emerich de Vattel, The Law of Nations, or Principles of the Law of Nature, Dublin, I787, pages 4I5-4I6. 
ments, and draw minds towards each other. His duty is to favor what is right, and to cause to be restored what belongs to each; but he ought not scrupulously to insist on rigorous justice. $\mathrm{He}$ is a moderator, and not a judge: his business is to procure peace; and to bring him who has right on his side, if it be necessary, to relax something with a view to so great a blessing. $* * *$ When sovereigns cannot agree about their pretensions, and yet desire to maintain, or to restore peace, they sometimes trust the decision of their disputes to arbitrators chosen by common agreement. As soon as the compromis (agreement) is concluded, the parties ought to submit to the sentence of the arbitrators; they have engaged to do this, and the faith of treaties should be regarded."

The German, J. B. Klüber, writing in the early part of the nineteenth century, says: $:^{14}$

"If the person who has been chosen [arbitrator] accepts, he has the right, after a discussion and a sufficient examination of the reasons pro and con, to pronounce the arbitral judgment (laudum) which he believes conforms with the principles of the Law of Nations."

${ }^{14}$ J. B. Klüber, Droit des Gens Moderne de L'Europe: Paris, Sec. 3 r 8 , page 457 . 
That is what Lord Stowell, for instance, attempted to do in the famous judgments which he gave when he sat in the High Court of Admiralty of England upon prize cases. It was his aim, he said, in the case of the Maria,$^{15}$ where Swedish vessels were involved, not to forget that while the seat of his Court was local, the Law between Nations which he was to apply in his Court was world wide in its application and as binding on one Nation as another. Nevertheless, like all municipal judges sitting in prize cases, his judgments in the long run were influenced undoubtedly in some degree by the needs of his own country to successfully prosecute the war in which she was engaged.

In our own times, as a result of the additional impetus given to the development of international justice as a means of avoiding war by the successful submission of the Alabama Claims for judgment to the Geneva Tribunal, a number of distinguished international publicists representing the best learning of many nations in the Law between Nations, may be mentioned, who have in one way or another expressed their understanding of what is meant by arbitration as a term of International Law.

Thus the Belgian, Gustave Rolin-Jaequemyns,

15 (I 799) I Christopher Robinson, pages 340, 350. 
the originator and one of the founders, in 1873 , of the Institut de Droit International, has clearly and forcibly enunciated his opinion on this point. Writing in I89I in the Revue de Droit International, of which he was one of the three founders as well as editor-in-chief for many years, he discusses the agreement between France and the Netherlands in I 888, which those two Nations modified two years later, to submit to the Emperor of Russia as arbitrator their difference over the frontier line between French and Dutch Guiana. In the convention as amended in $\mathbf{I} 890$ it was provided that the arbitrator "in case he did not reach, after an examination, to designate as a frontier one of the two rivers mentioned in the convention of $\mathbf{I} 888$, he was eventually authorized, for an intermediary solution, to adopt and decide upon another boundary which would pass through the contested territory." This new agreement, whereby the arbitrator was invested with authority, in case he could not decide in favor of the boundary claimed by one or the other of the two Powers, to impose upon the two Nations a compromise, was criticised severely in the States General of the Netherlands, because upon an arbitration demanding from the judge a decision based upon the evidence and the law, there was grafted a mediation. 
After pointing out that two States could, if they wished, graft upon the powers of an international arbitrator acting as a judge those of a mediator, that is of what is known as an aimable compositeur, Rolin-Jaequemyns went on to say:

"There is an International Law. This Law grows either from conventions, or from general principles accepted by civilized Nations. The essential object of resorting to arbitration between States is, not to create that Law, but to cause to be sought and decided by a temporary judge voluntarily chosenowing to the want of a permanent and obligatory jurisdiction-in what manner International Law is applicable to a given case, which is the cause of a disagreement between the parties. The States which accept arbitration recognize by that very thing (and it is that which gives to that procedure so great a value) that their difference is susceptible of being settled by the rules of International Law, either general or conventional. It is to falsify that idea and to compromise its application, to admit beforehand in the agreement (compromis) itself, the eventuality of a solution dictated, not by the Law, but by an arbitrary appreciation of the conveniences of each party."

In view of the above expressed opinion, especially 
the last sentence, it is evident that in the opinion of the founder of the Institut de Droit International, by the terms International Courts of Arbitration and International Arbitrators, are meant International Courts and International judges chosen to function temporarily so as to pass judgment in the light of the Law between Nations upon some designated case of difference between two or more Nations, just as Municipal Courts and Municipal judges give judgment in the light of Municipal Law upon cases of difference between individual citizens or corporations. There is, however, this difference between these two classes of jurisdiction. International Courts of Arbitration and International Arbitrators are appointed ad hoc to judge particularly designated cases, while Municipal Courts and Municipal judges are appointed with a continuing power in the exercise of a compulsive jurisdiction, to judge all cases that may be brought before them. But in both of these classes of jurisdiction, in the International as well as in the Municipal, the Courts are to decide according to the Law, in the one case according to the Law between Nations, in the other according to Municipal Law. Three years later, Louis Renault, the chief expert adviser upon the Law between Nations to the French Foreign Office, in commenting upon the Bering Sea 
Fur Seal case, expressed his conception of the nature of international arbitration. ${ }^{16}$ He says:

"The normal mission of arbitrators, whether they are appointed by Governments or by private individuals, is to decide a difference, to solve a question of Law or fact concerning which the parties are in disagreement. The arbitrators must find, from the documents produced, who is wrong or who is right; they pronounce a veritable judgment."

Then commenting on the conclusion made public on January Io, I831, by the King of the Netherlands as to the Anglo-American boundary which had been referred to him to decide as arbiter, Renault says:

"It was not truly a sentence; the arbitrator had not fulfilled his mission which was to judge and he had done what was not asked of him; in truth he had assumed the role of a spontaneous mediator, proposing a friendly solution of the difference."

Next discussing a boundary question between Great Britain and Portugal, in which case the contending Nations agreed in case the arbiter, the President of the French Republic, could not decide entirely in favor of the contention of one or the other

${ }^{16}$ Louis Renault, Une nouvelle mission donnée aux arbitres dans les litiges internationaux a propos de l'Arbitrage de Behring: Revue Générale de Droit International Public. Paris, 1894, pages 44-5r. 
Nation, that he should have the right then "to give such decision which, in his view, would offer an equitable solution of the difficulty," Renault, after remarking that this was not a strict case of mediation, since the sentence of the arbiter was to be accepted by both parties, whatever it might be, ${ }^{17}$ went on to say: ${ }^{18}$

"Thus the two States, foreseeing that their difference perhaps could not be settled by a juridical decision, and wishing nevertheless to settle it, gave to the arbiter a special power which went beyond the ordinary limits of the competence of a judge."

Then again, after discussing the Bering Sea case and the powers granted by the two litigant Nations to the International Court of Arbitration which sat in 1893 at Paris in judgment on that case, Renault says: $:^{19}$

"Two persons may have every reason to come to an agreement to form a partnership for example, or to make an exchange; if they do not do so, they merely make use of their natural liberty, and one cannot say that there is litigation between them.

${ }^{17}$ Protocol of September 25, 1872; de Clercq, Recueil des traités de la France, V., XI., page 39.

${ }^{18}$ Revue Générale de Droit International Public, Paris, I894, page 45. ${ }^{19} I d$., page 50 . 
In case, however, that they should be anxious to come to an understanding and should appoint a third party to define the conditions which would seem to him equitable for an arrangement, it would be wrong to call that third party an arbitrator, since his mission is in no manner that of a judge." And then in a foot-note to the passage just cited, the learned French publicist further says: "I know perfectly that arbitration in industrial affairs is understood in this sense, but it is so used in an inexact way."

These extracts from Renault make it clear that he considered, at the time he wrote, that an international arbitrator is a judge and not a reconciler.

In a letter printed in the London Times, January 6, I896, proposing a peaceful solution of the AngloVenezuelan crisis, John Westlake, then holder of the Whewell chair of International Law in Cambridge University, wrote:

"It is that of arbitration, with a restriction presently to be mentioned, combined with mediation. An arbitrator can only pronounce a judgment; he cannot make a recommendation as a mediator can. When England and the United States referred the boundary between Canada and Maine to the arbitration of the King of the Netherlands, that Sovereign 
did not adjudicate on the respective lines proposed by the parties, but proposed an intermediate one as a compromise, which the United States were not bound to accept and did not accept. Now in the present case it is more than probable that an arbitrator would find legal grounds enough for ruling out the maximum claims on both sides, even if he were not prevented from entertaining them by the restriction presently to be suggested. But it is also probable that for some part of the intermediate region he might be unable to find any legal grounds of decision, and that all he could do would be to propose a line of his own. Then, if the parties had from the beginning accepted him in the character of mediator as well as in that of arbitrator, they would not indeed be bound to accept a line which he did not declare to be one of legal obligation, but his proposal, made as it would be after hearing all that could be said on that branch of the subject, would carry such weight that no party desirous of peace would refuse to accept it."

Westlake, in his treatise International Law, in contrasting arbitration with mediation, says of the former of these two functions: ${ }^{20}$ "The essential

20 John Westlake, International Law, London (and ed.), Part I, page 354 . 
point is that the arbitrators are required to decide the difference-that is, to pronounce sentence on the question of right. To propose a compromise, or to recommend what they think best to be done, in the sense in which best is distinguished from most just, is not within their province, but is the province of a mediator."

Earlier in the same work, in commenting on the general division between the differences that arise between Nations which seem capable of being decided by International Courts upon legal grounds and those which because of the great political interests involved for the Nations concerned, apparently cannot be so settled, Westlake also says:." "That distinction is not eo nomine one of old standing in the theoretical treatment of international law. It has been brought into prominence under the nomenclature of legal or juridical and political by the discussions and negotiations on arbitration, which is essentially a juridical proceeding. "22

From the three above quoted passages it is very evident that Westlake considered that International Courts of Arbitration have not the right to arrange the cases which they are called on to decide by a

${ }^{21}$ J. Westlake, International Law, London, 2nd ed., Part I., page 305.

22 The italics have been added by the present writer. 
compromise arrangement, that attribute being the proper function of mediation. On the contrary, judging from the above quoted extracts, Westlake evidently considered that international arbitrators and International Courts of Arbitration in passing upon differences between Nations were to decide upon legal grounds.

The delegates of Russia, among them Fedor de Martens, to the First Hague Peace Conference in I899 addressed to the representatives of the other twenty-five Powers who took part in that gathering of the Nations, memoranda in which the merits of and the distinction between mediation and arbitration were discussed. ${ }^{23}$ In the first memorandum, the Russians pointed out that the difference between good offices and mediation was more theoretical than real, and also that "mediation does not impugn in any way the principle of the sovereignty, liberty and independence" of states. In a second memorandum, the Russian delegates noticed the difference between voluntary and obligatory arbitration, and pointed out that "it is difficult to conceive of a differ-

${ }^{23}$ Blue Book: C. 9534 miscellaneous, No. I (1899). Correspondence respecting the Peace Conference held at The Hague in 1899. Presented to both Houses of Parliament by Command of Her Majesty, Oct., 1899, pages 39-45. 
ence of a legal nature, arising within the scope of positive International Law which could not as a result of an agreement between the parties, be solved by means of optional International Arbitration." Concerning compulsory arbitration, the Russian report pointed out very wisely that it cannot be applied to every kind of disputes. "There is no government," it says, "which would consent to accept beforehand the obligation to submit to the decision of the Tribunal of Arbitration every difference which might arise in the domain of international relations if it affected the national honor of the State, its highest interests and its imprescriptible wealth. Actually, the reciprocal rights and obligations of States are determined, in a notable measure, by the general consensus of what are called political treaties, which are nothing else than the temporary expression of fortuitous and transitory relations between the different national forces. These treaties bind the freedom of action of the parties so long as the political conditions which produced them remain without change. When these conditions change, the rights and obligations resulting from these treaties necessarily change also. As a general proposition, the conflicts which arise over political treaties turn in most cases, not so much on a difference in the inter- 
pretation of such and such a rule, as on the change to be made in the provisions of the treaty or its complete abrogation. Consequently the powers which take an active part in the political life of Europe, cannot submit the differences which arise out of the political treaties to a Court of Arbitration, in the eyes of which what is laid down by treaty would be as binding and inviolable as what is laid down by the positive law is in the eyes of a national Court of Justice." ${ }^{24}$

Thus in the report presented by the Russian delegates to the representatives of the other nations who were parties to the First Hague Conference, it is distinctly affirmed that an International Court of Arbitration, like "a national Court of Justice," is, in giving its judgment, bound by the Law, in the one case by the Law between Nations, in the other by the Municipal Law of the country where the National Court has its seat.

Last but not least, the learned American jurist, John Bassett Moore, speaking of mediation and arbitration, says: $:^{25}$ "These methods are often discussed as if they were practically the same, but in

\footnotetext{
24 The italics have been added by the present writer.

${ }^{25}$ John Bassett Moore, International Law Digest, Washington, I906, Volume VII., page 25.
} 
reality they are fundamentally different. Mediation is an advisory, arbitration a judicial, function. Mediation recommends, arbitration decides. While nations might for this reason accept mediation in various cases in which they might be unwilling or reluctant to arbitrate, it is also true that they have often settled by arbitration questions which mediation could not have adjusted.

"It is, for example, hardly conceivable that the question of the Alabama Claims could have been settled by mediation. The same thing may be said of many and indeed of most of the great number of boundary disputes that have been settled by arbitration. The importance of mediation as a form of amicable negotiation should not be minimized. * * * Nevertheless, mediation is merely a diplomatic function and offers nothing new.

"Arbitration, on the contrary, represents a principle as yet only occasionally acted upon, namely, the application of law and of judicial methods to the determination of disputes between nations. Its object is to displace war between nations as a means of obtaining national redress, by the judgments of international judicial tribunals, ${ }^{26}$ just as private war between individuals, as a means of obtaining personal

26 The italics have been added by the present writer. 
redress, has, in consequence of the development of law and order in civilized states, been supplanted by the processes of municipal courts. ${ }^{27}$ In discussing the subject of arbitration, we are therefore to exclude from consideration, except as a means to that end, mediation, good offices, or other forms of negotiation."

It is quite evident from the foregoing review of some of the leading dictionaries as well as the writings of some of the leading publicists, that the word arbitration in Municipal affairs has very much changed its meaning and departed from the use of the word as a term of International Law. And in this connection it will be useful to notice how the meaning of another word has changed as the years have rolled by.

Thus the word State as used in the North American Confederation between I78I and I789, and since the adoption of the Constitution, has changed its meaning. As applied to the original thirteen States of the Confederation before I789, the word State meant a member of the family of Nations, a sovereign State, for originally the thirteen States constituted a Confederation composed of thirteen member States. To-day, however, the word State as appliea to the

27 The italics have been added by the present writer. 
forty-eight members of the Federal Union does not mean the same thing that it did in the times of the Confederation. For neither Pennsylvania, nor New York nor any other of the forty-eight States composing the United States of America to-day is a member of the family of Nations, as France is a State and a member of the family of Nations. These forty-eight States together form not forty-eight Nations, but only one single Nation. But the change in the meaning of the word State in the historic development and evolution by which the original Confederation of thirteen States became the one Nation of to-day known as the United States of America, does not alter the historic fact, that originally as applied to the thirteen States the word State meant thirteen separate and distinct members of the family of Nations, while to-day the same word means the various units of the North American Union, that is, the component parts of but one single member of the family of Nations.

II.

It has been urged of late, that an International Arbitrator is not bound by the Law, as a Judge, sitting in a regularly constituted Court, is bound by 
the Law. In other words, that an International A rbitrator can exercise, in reaching his opinion in the case submitted to him for a settlement, his own ideas of what would be a just judgment, and so is likely to try to settle the case by a compromise ${ }^{28}$ which will please in part both sides to the dispute; while on the contrary, a Judge, sitting in his Court, cannot allow his own personal feelings of justice to influence his judgment, but must rigorously base his opinion upon the Law applicable to the case before him. As a result of the above reasoning, it is maintained by some writers and practitioners that an International Arbitrator tends to become a reconciler, that is, a mediator, a compositeur aimable, in contrast with the Municipal Judge, who always gives a judicial opinion based on legal reasoning.

That the Judges of Municipal Courts, even the most learned and.distinguished who have sat in the highest Tribunals in the world, never allow either their own ideas or consciences to influence them in arriving at their opinions as to what most closely is justice in each particular case, is, however, an

${ }^{28}$ It is well to remember that the French word compromis does not mean compromise but agreement. Compromis is often wrongly translated into English by those who do not know better by the word compromise instead of by the word agreement. 
absurdity of statement, which even a cursory examination of the cases disproves.

Take, for example, the rise and development of the rule of the Law between Nations that the jurisdiction of the Courts of Nations with a maritime front on the open sea extends to the distance of one marine league, or three miles, from low water. It was during an embassy sent by the United Netherlands to the English King James the First, in 16ro, that the idea of limiting the exclusive sovereignty of a maritime State to the distance of a cannon shot from its shore was first publicly put forward. This development was an incident in the long drawn out battle between the English and the Hollanders over the right to fish, which the latter claimed to exercise, and did exercise, in the sea between England and the continent. "No prince," the Dutch envoys told the English representatives, "can Challenge further into the Sea than he can Command with a Cannon, except Gulfes within their Land from one point to another." 23 While the idea of placing a limit on the exclusive seaward jurisdiction of a State doubtless had occurred before, it seems then for the first time to have taken concrete form in the cannon shot limit.

29 Thomas Wemyes Fulton, The Sovereignty of the Sea, Edinburgh, I9I I, page $x_{56}$. 
Perhaps it originated in the fertile brain of Grotius, though he was not a member of the embassy. For in a work he wrote in 1618 , which was published at Paris in I640, Grotius refers to this principle of the cannon shot having been urged on the English. ${ }^{30}$ Later the idea that a reasonable limit should be placed upon the power of a maritime State to control the sea coast adjoining its coast line was advocated by another Dutch publicist, hardly less renowned than Grotius, Cornelius van Bynkershoek. Then the idea was slowly taken up with favor, with varying distances, by various jurists, both publicists and judges. The three mile limit, as the equivalent of the cannon shot from shore, was first advanced by a Government, apparently, in a note which Thomas Jefferson, the Secretary of State of the United States of America, wrote on November 8, I793, to M. Genêt, the French envoy. ${ }^{31}$ The three mile limit next received a great impetus from the decisions of Sir William Scott, later Lord Stowell, sitting in the High Court of Admiralty of England.

${ }^{30}$ Apologeticus eorum qui Hollandiae Westfrisiaeque et vicinis quibusdam nationibus ex legibus praefuerunt ante mutationem quae evenit anno 1618. Scriptus ab Hugone Grotio, I. C.; Paris, 1640, page 383 .

31 American State Papers: Foreign Relations, Washington, 1832, Volume I., page I83. 
By his judgments in the two cases of the Twee Gebroeders $^{32}$ and the case of the Anna, ${ }^{33}$ he gave the judicial sanction of the greatest maritime power of the world to the three mile limit of the territorial sea, and introduced that limit into English Law. In the first Twee Gebroeders case, that vessel was taken on August 14, 1799, on a voyage from Emden to Amsterdam, which latter place was under blockade. She was captured on the Groningen Wat, near the coast of East Friesland. The Prussian Government suggested that the vessel was captured within the protection of Prussian territory. In considering the extent of the Prussian jurisdiction over the sea adjoining its coast, Sir William Scott said, in $1800:^{34}$

"She was lying in the Eastern branch of the Eems, within what may I think be considered as a distance of three miles, at most, from East Frieslands; an exact measurement cannot easily be obtained; but in a case of this nature, in which the Court would not willingly act with an unfavorable minuteness

${ }^{32}$ Twee Gebroeders, Alberts master (1800) 3 Christopher Robinson, page 162, and Twee Gebroeders, Northolt master (1801) id., page 336.

${ }^{33}$ The Anna (1805) 5 Christopher Robinson 373.

${ }^{34}$ Twee Gebroeders, Alberts master (1800) 3 Christopher Robinson I62, at page 163 . 
towards a neutral State, it will be disposed to calculate the distance very liberally; and more especially, as the spot in question is a sand covered with water only on the flow of the tide, but immediately connected with the land of East Friesland, and when dry, may be considered as making part of it. I am of opinion, that the ship was lying within those limits, in which all direct hostile operations are by the Law of Nations forbidden to be exercised."

The second Twee Gebroeders case, decided in I80I, arose on the capture of a number of vessels bound from Hamburg to Amsterdam, which latter port was under blockade. In the decision, Sir William Scott held ${ }^{35}$ "In the sea, out of the reach of cannon shot, universal use is presumed."

In the case of the Anna, captured at the mouth of the Mississippi River, and decided in 1805 , when the same learned authority held that the territorial sea should be measured, not from the mainland, but from some low lying islands or mudbanks at the mouth of the river, Sir William Scott cited one of the famous maxims of Bynkershoek and translated it into three miles from the shore. He said $:^{36}$

\footnotetext{
${ }^{35} 3$ Christopher Robinson 336, at page 339 .

${ }^{36}{ }_{5}$ Christopher Robinson 373 , at page $385 \mathrm{c}$.
} 
"We all know that the rule of law on this subject is 'terrae dominium finitur, ubi finitur armorum vis,' and since the introduction of fire-arms, that distance has usually been recognized to be about three miles from the shore."

When Sir William Scott gave those decisions there was no fixed and hard rule of the Law between Nations that obliged him to decide as he did. On the contrary, he exercised his own ideas, arriving at his decisions of what would be most just in these cases. In giving these three judgments he was not governed by a rule of the Law between Nations recognized by all Nations, but, on the contrary, he gave the English interpretation on that point, and so helped to develop the Law between Nations. The three mile limit came to be recognized in the larger part of the world more and more as the extent of the territorial sea. There were exceptions to it a century ago, as there are exceptions to it to-day. But by the year I 876 it had gained the support of the great majority of publicists, and the support of many governments through the acts of their officials in one way or another, including that of England as expressed in the judgments of Lord Stowell in her High Court of Admiralty. Then in the year 1876 occurred the case of the Queen v. Keyn, better known as the case of the Franconia. That case 


\section{I}

turned on whether the jurisdiction of the English Courts extended over the territorial sea. Briefly, that case was as follows: The Franconia, a German vessel bound from Hamburg to St. Thomas, sank, less than three miles from the British coast, near Dover, the Strathclyde, a British vessel, killing as a result a woman, a British subject, who was on board of the British vessel. The crucial question in the case when it came up on appeal from the Central Criminal Court, was whether that Court had jurisdiction to try Keyn, a foreigner, who was the captain of the Franconia. By a majority of one, seven judges against six, the Court of Exchequer Division reversed the lower court, and held that the prisoner, a foreigner on a foreign ship within the marine belt, was not amenable to the Law of England, but only to that of his own country. The minority judges practically agreed that-as shown by the custom and usages of Nations and proclaimed by the writings of the publicists - the rule of the Law between Nations, by which the sovereignty of Nations having a sea coast was extended seaward over the marine belt known as territorial waters, had extended the sovereignty of England over the territorial sea adjoining her coast, and so had placed the marine belt under the jurisdiction of her Courts. That view 
was well stated by Chief Justice Coleridge, who said in part: $:^{37}$

"Now my brothers Brett and Lindley have shown that by a consensus of writers, without one single authority to the contrary, some portion of the coast waters of a country is considered for some purposes to belong to the country the coasts of which they wash. I concur in thinking that the discrepancies to be found in these writers as to the precise extent of the coast waters which belong to a country (discrepancies, after all, not serious since the time at least of Grotius) are not material in this question; because they all agree in the principle that the waters, to some point beyond low-water mark, belong to the respective countries, on grounds of sense if not of necessity, belong to them as territory or sovereignty, in property, exclusively, so that the authority of France or Spain, of Holland or England, is the only authority recognized over the coast waters which adjoin these countries. This is established as solidly as, by the nature of the case, any proposition of international law can be. * * * The law of nations is that collection of usages which civilized states have agreed to observe in their dealings with one another.

${ }^{37}$ The Queen v. Keyn (1876) Law Reports, 2 Exchequer Division 63, at page $\mathbf{I} 53$. 
What these usages are, whether a particular one has or has not been agreed to, must be matter of evidence. Treaties and acts of state are but evidence of the agreement of nations, and do not in this country at least per se bind the tribunals. Neither, certainly, does a consensus of jurists; but it is evidence of the agreement of nations on international points; and on such points, when they arise, the English Courts give effect, as part of English Law, to such agreement."

The majority judges, however, reversed the lower Court, and held that a rule of the Law between Nations, no matter how many learned jurists agreed in proclaiming it a rule of that Law, nor no matter how many other Nations might agree among themselves that such a rule was a part of the Law between Nations, was not binding upon British Courts until the British Parliament had enacted it as a rule of Law. While the majority of judges were not altogether unanimous, most of them agreed with the view expressed by Lord Chief Justice Cockburn, that the extent of the realm of England is a question of English and not International Law.

Lord Chief Justice Cockburn said: ${ }^{38}$

${ }^{38}$ The Queen v. Keyn (1876) Law Reports, 2 Exchequer Division 63, at page 202 . 
"Can a portion of that which was before high sea have been converted into British territory without any action on the part of the British Government or legislature-by the mere assertions of writers on public law-or even by the assent of other nations?

"And when in support of this position, or of the theory of the three mile zone in general, the statements of the writers on international law are relied on, the question may well be asked, upon what authority are these statements founded? When and in what manner have the nations, who are to be affected by such a rule as these writers, following one another, have laid down, signified their assent to it? To say nothing of the difficulty which might be found in saying to which of these conflicting opinions such assent had been given."

Further on in his opinion Lord Cockburn said that writers on the Law between Nations, "however valuable their labours may be in elucidating and ascertaining the principles and rules of Law, cannot make the Law." Even the unanimous assent of the Nations that the three mile zone of so called territorial waters around Great Britain was under British jurisdiction, he maintained, would not justify British Tribunals in recognizing, "without an 
Act of Parliament, what would practically amount to a new law."

Thus thirteen British judges sitting together on a case, after weighing the facts, the opinions of jurists and publicists and the acts of other Nations, were unable to agree and divided almost equally upon the question whether a rule of the Law between Nations could become grafted upon the Law of England through the long continued customs and acts of many Nations as evinced by treaties and other diplomatic acts, and the writings of the publicists; or whether it required an Act of Parliament to make a rule of the Law between Nations binding on British Courts. The decision destroyed the marine belt so far as the jurisdiction of British Tribunals was concerned, and the Law as proclaimed by the decision of the Court had to be changed to meet the requirements of the future obligations of Great Britain as a member of the family of Nations, by the Territorial Waters Jurisdiction Act of 1878 . Thus in that important case thirteen judges, when called upon to pass upon a case for which no exact precedent could be found among English decisions, had to use, each individually, in making up their minds as to whether the jurisdiction of British 
Courts extended over the marine belt of International Law, their own best judgments. As a result, far from agreeing, they divided into two almost evenly balanced groups, and neither of these two groups was altogether unanimous in the processes by which they arrived at their conclusions. This is a splendid example showing how judges on the Bench not only do exercise their own individual ideas in arriving at their opinions, but also on many occasions are absolutely forced by the exigencies of the case before them to call upon and sometimes even to rely upon their own consciences in deciding what will be a just decision.

Take another case, one that was appealed to and heard by the most notable Municipal Tribunal in the world, the Supreme Court of the United States, the case known under the name of the Paquete Habana. ${ }^{39}$

At the beginning of the war in 1898 between the United States and Spain, two Spanish fishing vessels, the Paquete Habana and the Lola, were taken by the American blockading squadron off the coast of Cuba and condemned by a Federal District Court as prizes of war. The case was appealed to the Federal Supreme Court. The nine members of that Court

${ }^{39}$ (1900) I 75 United States Supreme Court Reports 677. 
divided into two groups, of six to three. The majority, Mr. Justice Gray delivering the opinion of the Court, held, after a careful and exhaustive review of the works of the publicists and the decisions of the Supreme Court and other Tribunals, that through custom a rule of International Law had grown up exempting from capture in times of war the fishing vessels of belligerents who were merely pursuing their calling. The exemption does not hold good, Justice Gray said, if the fishing vessels engage in hostilities in any way, nor does it apply to fish taken in the deep sea so far from land that the fish cannot be brought to market fresh, but must be salted or otherwise cured. President McKinley, in his proclamation of April 26, 1898, made no specific mention of fishing vessels. "But the proclamation clearly manifests," Justice Gray says, ${ }^{40}$ "the general policy of the Government to conduct the war in accordance with the principles of international law sanctioned by the recent practice of nations."

Chief Justice Fuller, Justices Harlan and McKenna concurring with him, gave the dissenting opinion of the minority of three judges. He did not agree that there was any such established rule of the Law

${ }^{40} 75$ United States Supreme Court Reports, page 712. 
between Nations. In his opinion, after referring to the decision of the District Court condemning the two vessels and their cargoes, because the lower Court was not, as he quoted the opinion of the lower Court," "satisfied that as a matter of law, without any ordinance, treaty or proclamation, fishing vessels of this class are exempt from seizure," the Chief Justice went on to say: ${ }^{42}$

"This Court holds otherwise, not because such exemption is to be found in any treaty, legislation, proclamation or instruction, granting it, but on the ground that the vessels were exempt by reason of an established rule of international law applicable to them, which it is the duty of the Court to enforce.

"I am unable to conclude that there is any such established international rule."

There, speaking for the minority of the Tribunal, the Chief Justice absolutely disagreed with the judgment of the Court given by Justice Gray.

Then further in his dissenting opinion, the Chief Justice said: $:^{43}$

"In truth, the exemption of fishing craft is essen-

\footnotetext{
${ }^{41} 175$ United States Supreme Court Reports, page 715.

${ }^{42}$ Ibid, page $7 \mathrm{r} 5$.

${ }^{43}$ Ibid, page 7 ro.
} 
tially an act of grace, and not a matter of right, and it is extended or denied as the exigency is believed to demand.

"It is," said Sir William Scott, "“ a rule of comity only, and not of legal decision.",

After citing Hall, Freeman Snow, and other authorities, the Chief Justice continued $:^{44}$

"In my judgment, the rule is that the exemption from the rigors of war is in the control of the executive. He is bound by no immutable rule on the subject. It is for him to apply, or to modify, or to deny altogether such immunity as may have been usually extended."

In this case, the Court had to decide whether there had grown up by custom through centuries of practice a rule of the Law between Nations exempting fishing vessels when peacefully engaged in their calling from capture as prizes of war, or whether there had merely developed a rule of courtesy among Nations, enabling the executive of each Power to exempt from capture the fishing vessels of an enemy country. And the members of that august Tribunal were not agreed in their conclusion, the majority deciding that there had grown up through long continued custom and usage such a rule of International

${ }^{44} 75$ United States Supreme Court Reports, page 720. 
Law, while the minority just as firmly held that there had not.

To take the practice of a Municipal Court as an example, let us look at a notable Pennsylvania case. The Pennsylvania Supreme Court reversed its own earlier judgments in the case of Sanderson v. The Pennsylvania Coal Company concerning the flow of water in the anthracite coal districts of Pennsylvania. ${ }^{45}$ Why? Because, owing to the development of coal as a factor in the modern commercial world, there was a difference of opinion from the first among the judges composing the Court as to how the case should be decided. It was a case for damages caused by the water pumped out of a mine that flowed into a stream which was thereby polluted. The case was argued four times before the Supreme Court of the State of Pennsylvania. Not a single judge changed his opinion, but gradually as the personnel of the Tribunal changed, the Court changed its view, and so reversed itself. The final decision of the Court was practically based on the

${ }^{45}$ Sanderson v. The Pennsylvania Coal Co. (1878) 86 Pennsylvania Supreme Court 40r; Pennsylvania Coal Co. v. Sanderson (1880) 94 Pennsylvania Supreme Court 302; Sanderson v. Pennsylvania Coal Co. (1883) 102 Pennsylvania Supreme Court 370; The Pennsylvania Coal Co. v. Sanderson (1886) II3 Pennsylvania Supreme Court $\mathbf{2} 26$. 
kernel of the dissenting opinion of Justice Paxson, the first time the case came before the Court, when he said: "The plaintiffs knew when they purchased their property that they were in a mining region."

Thus in that important case which was taken four times for decision to the highest Tribunal of the State, the members of the Court from the start were unable to arrive at a unanimous decision. They persistently disagreed, some deciding for one party to the case, and others for the other contestant.

In addition, in considering the latitude allowed to judges in exercising their own individual ideas and conceptions of what would constitute justice in any given case, it is well to remember that the English Common Law, owing in many instances to the rigidity of its rules and the inability in earlier times to change and amend it, caused the rise of Equity and the Court of Equity, which could afford relief in cases where the Common Law could not. And to-day in many jurisdictions the two systems of jurisprudence have been consolidated, the Courts in some jurisdictions sometimes sitting as Courts of the Common Law, sometimes as Courts of Equity, while in other jurisdictions, as for example in Pennsylvania, the Courts sit as Tribunals which concurrently administer both the Common Law and the Law of 
Equity in arriving at their decisions. Thus when the judges of the Common Law Courts were so bound by the Law that they could not in many cases exercise their personal common sense and conscience, relief for such a situation was sought by combining, in varying decrees in different jurisdictions, with their functions as Common Law judges the powers of chancellors of Equity, and so allowing to the judges greater flexibility in arriving at their decisions than could have been possible had they remained strictly Common Law judges.

Further, it must be remembered that the judges of Municipal Courts who have acted as judges in Prize Courts, in their interpretation of the Law between Nations have leaned undoubtedly towards the view that favored in the long run their own country. For instance, take the judgments of Lord Stowell, when he was in great measure forming the Law of the Sea,- - can anyone doubt that in rendering his judgments he was influenced in some degree by the interests of England as a belligerent? So, too, the Supreme Court of the United States during the Civil War, in the matter of continuous voyages, undoubtedly leaned towards the point of view that favored the Union cause. And so also with the Tribunals of other Nations. For after all, judges, 
even the most conscientious of them all, are human beings. Such personal views are easier of application in the earlier and formative period of the Law, whether Municipal or International, than when the Law has reached a highly developed stage. Nevertheless, even when the Law is highly developed, the personal feelings and ideas of each judge as to what constitutes justice in each case counts for something, more or less according to the character of the individual judge and the circumstances of each case.

From the three cases of the Queen v. Keyn, the Paquete Habana and Sanderson v. The Pennsylvania Coal Company, that have been reviewed above, it is evident that Municipal judges, sitting together in the same Municipal Courts, frequently do not agree as to the proper judgments to be rendered in the cases submitted to them for decision. It may be urged, however, in all cases where the judges of a Municipal Tribunal disagree as to their judgments upon a case before them, that they all of them have given a decision in favor of one side or the other, and that they do not agree upon a compromise with the view of giving something to each contestant to a case so as to reconcile both parties to the judgment of the Court. In other words, that in those cases where the judges of Municipal Courts fail to agree in their 
opinions as to the case before them, they disagree upon legal grounds, and each judge or group of judges in giving a decision favorable to one side or the other, does not seek to find in his or their judgment a happy medium pleasing to both sides of the case argued at the bar.

Cases, however, have been tried in Municipal Tribunals when the judges of such Courts, just as much as the members of some International Courts of Arbitration, have sought to settle cases before them upon the basis of a compromise between the contestants rather than by handing down a decision founded upon pure legal reasoning which is clearly cut in favor of one side or the other.

During the great American Civil War of I86I-I865, the Supreme Court of the United States had many cases brought to its bar involving the principle of continuous voyages. One of these was the case of the Bermuda. ${ }^{46}$ That vessel, before her capture, had made a voyage bound ostensibly from London to Bermuda. Eventually she ran the blockade, maintained by the United States of the Confederate coast, to Savannah. On that voyage she had a cargo that would have been of great value in any of the Confederate ports. She returned successfully

${ }^{46}$ (1865) 3 Wallace, United States Supreme Court Reports, page 514. 
to England. On her first outward voyage from England, while Haigh, a British subject, was her apparent owner, he had given a power of attorney to sell the ship to two inhabitants of Charleston, South Carolina.

After her return to England, she received at Liverpool preparatory to a second voyage, a cargo under the direction of Fraser, Trenholm and Co., a firm having connections in Charleston. On her second voyage the Bermuda was bound again ostensibly for Bermuda. The vessel was captured by a Federal cruiser on the high seas and sent into Philadelphia. After both the ship and cargo had been condemned by the District Court as good prizes, the case was appealed to the Federal Supreme Court, where the judgment of the lower Court was affirmed.

Chief Justice Chase in giving the opinion of the Court said : $:^{47}$

"Now, what were the marks by which the conveyance of contraband on the Bermuda was accompanied? First, we have the character of the contraband articles, fitted for immediate military use in battle, or for the immediate civil service of the rebel government; then the deceptive bills of lading requiring delivery at Bermuda, when there was

\footnotetext{
${ }_{37}^{4}$ Wallace, United States Supreme Court Reports, page 557.
} 
either no intention to deliver at Bermuda at all, or none not subject to be changed by enemies of the United States; then the appointment of one of these enemies as master, necessarily made with the knowledge and consent of Haigh, if he was owner; then the complete surrender of the vessel to the use and control of such enemies, without even the pretence of want of knowledge, by the alleged owner, of her destined and actual employment." The Bermuda was justly liable, the Chief Justice continued, to condemnation for the carriage of contraband goods to a belligerent port under circumstances of fraud and bad faith which made the owner liable and responsible "for unneutral participation in the war." 48

The case of the Hart, ${ }^{49}$ tried soon after that of the Bermuda, was very similar. The vessel had a cargo of arms and munitions of war, taken on board chiefly at London under the direction of Confederate agents. The nominal destination of the vessel and cargo was Cardenas, Cuba; but the proofs of evidence were clear that the real destination after reaching Cardenas was to be a port of the Confederacy.

48 (1865) 3 Wallace, United States Supreme Court Reports, page $55^{8}$.

${ }^{49}$ Ibid, page 559. 
Chief Justice Chase said: $:^{50}$

"The case in its principal features resembles that of the Bermuda and her cargo; they are, perhaps, even more irreconcilable with neutral good faith.

"It is enough to say that neutrals who place their vessels under belligerent control, and engage them in belligerent trade, or permit them to be sent with contraband cargoes under cover of false destination to neutral ports, while the real destination is to belligerent ports, impress upon them the character of the belligerent in whose service they are employed, and cannot complain if they are seized and condemned as enemy property."

The lower Court's decree condemning both the vessel and cargo was affirmed. ${ }^{51}$

${ }^{50} 3$ Wallace, United States Supreme Court Reports, page 560.

51 The doctrine of continuous voyages affirmed in these two cases of the highest American Court as a rule of the Law between Nations, while not accepted as sound by all publicists and all nations, was later, during the South African Three Years' War, acted upon by Great Britain in the case of the German steamers, Bundesrath, Herzog and General. Those three vessels bound in 1900 from neutral German ports to the neutral Portuguese port of Lorenzo Marques on Delagoa Bay, were seized by cruisers of Great Britain because these neutral vessels were thought to be carrying contraband of war destined for the two Boer Republics. The German Government demanded their release on the ground that as they were sailing between neutral ports, there could not be said to be any carrying of contraband between the neutral ports. Great Britain did not recognize the principle advanced by Germany, and 
If the decisions in the cases of the Bermuda and Hart are compared with the judgments in the cases of the Springbok and the Peterhoff, also tried a little later by the Federal Supreme Court of the United States, it becomes apparent that some decisions at least of Municipal Tribunals of the highest degree, possessing a continuing and compulsory jurisdiction, may be open to attack or unfavorable criticism as compromises, rather than judgments judicial in character, with quite as much justice and plausibility as many of the decisions of International Courts of Arbitration appointed ad hoc, which, possessing merely a temporary existence, do not enjoy a compulsory jurisdiction, but rely on the previous agreement and willingness of the litigant Nations to accept and loyally carry out the decisions handed down by such temporary International Tribunals. To put it in other words, many of the International Courts of Arbitration appointed ad hoc, whose judgments have been severely attacked, often by more or less interested parties, as compromises rather than judicial decisions, were no more guilty in that respect than Municipal Tribunals in many

asserted that, even though carried in a neutral vessel bound for a neutral port, articles intended ultimately for the enemy were contraband of war. 
decisions which the latter have handed down; and in many instances did render judicial decisions which have been unjustly attacked as compromises.

The Springbok sailed from London, December 8th, I862, and was captured about one hundred and fifty miles east of Nassau, a port in one of the British West Indies, February 3rd, 1863 , when bound to that port. ${ }^{52}$ Both ship and cargo were condemned by the District Court, and the case was appealed to the Federal Supreme Court.

The shipping articles engaged the crew not only from London to Nassau, but also from there, Chief Justice Chase said, ${ }^{53}$ if necessary, to any other West Indian, British North America or American port, and finally to a British port, "and it is also true that this engagement would include, should the master undertake it, a continuance of the voyage for the conveyance of the cargo from Nassau to a blockaded port; but there is no proof that there was any engagement for such continuance of the voyage."

The ship's papers seemed to show, the Court thought, no intention to take the goods further than Nassau, though the master was uncertain in his

${ }^{52}$ The Springbok (1866) 5 Wallace, United States Supreme Court Reports, page $\mathbf{r}$.

${ }^{53}$ Id. page $2 \mathrm{I}$. 
testimony as to the real ownership of the cargo. The Court decided that the ship was not involved with the contraband part of the cargo, but was in good faith carrying it to a neutral port, Nassau, so the vessel was not condemned by the Court, though the judgment of the lower Court was affirmed as to the cargo.

On the whole review of the case it would seem that the Court was anxious not to condemn a merchant vessel of a powerful neutral State whose government had been none too friendly to the Union cause; and, although there was evidence that seemed to show that the Springbok could have been continued for a Confederate port when captured in the region of the port of Nassau, a port well known to be in service as a base for running the blockade, the Court nevertheless discharged the vessel. While in the case of the Springbok the suspicion of unneutral service on the part of the vessel was not overwhelming, still it distinctly existed, and so gives strong color to the thought that the decision of the Court in that case in not condemning the vessel was a desire to reach a compromise which would be more or less pleasing to both Nations.

The Peterhoff, a British vessel, bound from London to Matamoras in Mexico, forty miles up the 
Rio Grande and opposite Brownsville in the Confederate States, was seized February 25th, I865, by a United States war vessel near the island of Saint Thomas. ${ }^{54}$ The cargo, which was miscellaneous in character, was in part useful for military purposes. It consisted also of iron, steel, many drugs and other things which, owing to the blockade of the Confederacy by the Federal Government, were much needed in the Confederate States. When the Peterhoff was captured by the United States cruiser Vanderbilt, not only did the captain of the Peterhoff refuse to go on board the war vessel to have his papers examined, on the ground that, as he was carrying a British mail, all his papers should be examined on his own ship, but also papers or articles of some sort were thrown overboard by his command and lost. The captain of the Peterhoff, in addition, admitted in Court that he had destroyed some letters, which he swore were addressed to him by his wife and father, but that no other papers were destroyed. The cargo was shipped mostly by various British subjects, and a portion of it belonged to the owner of the vessel. The New York District

${ }^{54}$ The Peterhoff (I866) 5 Wallace, United States Supreme Court Reports, page 28 . 
Court condemned both the vessel and the cargo as lawful prizes of war.

The Federal Supreme Court decided that part of the cargo was contraband, and that so much of the rest of the cargo as was not contraband, but belonged to the owner of the contraband, must be condemned. The Court, however, did not condemn the rest of the cargo, nor the vessel, on the ground that there was no intention of the vessel's attempting to break the blockade. In view of the throwing into the sea of some papers or some object from the vessel at the time the capture was taking place, and the master's admission in Court that he had destroyed papers which he alleged were merely letters from his wife and father, it would seem that the Court was lenient in its decision, preferring not to press too hard on the neutral owners either of the vessel or of a large part of the cargo. A comparison of the judgment in this case with those in the cases of the Bermuda and the Hart, in view of the strange doings of the master of the Peterhoff in destroying papers on board his vessel and throwing a package into the sea at the time of the capture of the Peterhoff, strongly suggests that the judgment of the Court in this case was very possibly a compromise.

The Supreme Court of the United States in both 
the case of the Springbok and that of the Peterhoff, while sustaining the lower Courts in their judgments as to the condemnation of the contraband portion of the cargo, had, nevertheless, a good and abundant reason to be lenient wherever it was possible upon the vessels of Great Britain, a strong neutral nation, because Great Britain throughout the war had often shown that she was jealous of the rise and growth of the United States. While it cannot be affirmed positively that the judgments handed down by the Federal Supreme Court in the cases of the Springbok and the Peterhoff were compromises, nevertheless, those two decisions are open to criticism as compromises rather than strictly judicial judgments with quite as much plausibility and accuracy as a number of judgments given by International Tribunals set up ad hoc, which have been criticised by some writers as being compromises.

A comparison of the decisions in the cases of the Queen v. Keyn and the Paquete Habana with those in the cases of the Alabama Claims and the Bering Fur Seal Fisheries is illuminative of the subject under discussion. In many important respects those two pairs of cases-the one pair tried before Municipal, the other before International Tribunals-are very similar. 
In the two former of these four cases, the two which were argued before and decided by two notable Municipal Tribunals, the Court in neither case was unanimous. The same thing was true of the latter two cases, the two which were tried and decided by International Courts of Arbitration. In the Queen v. Keyn the Court divided seven judges to six, and in the Paquete Habana six to three. In the Alabama Claims case the Tribunal divided on some counts four to one, on others three to two, and in the Bering Fur Seal case, on the question of the extent of the territorial sea the Court was six to one in favor of the three mile limit and five to two on some other points of the case. In all four of those cases the judges, both Municipal and International, had to rely in part on their own individual consciences and common sense in arriving at their decisions. In other words they had to decide something that had never been decided before. Another point of similarity is to be found in the Queen v. Keyn and the Alabama Claims cases. In each of those two cases, one tried before a Municipal, the other before an International Tribunal, legislation was called into play. As a result of the decision in the Queen v. Keyn, which abolished the territorial sea so far as English Law and English Courts were concerned, Parliament had to 
come to the rescue in the Territorial Waters Jurisdiction Act of August 16, 1878, to remedy the resulting situation which placed Great Britain in a way, as a result of that decision, outside of the pale of International Law. By that act, Parliament not only overruled the decision of the Court in the Queen v. Keyn, but even went so far as to say that that decision was wrong in its interpretation of the Law in the past. ${ }^{55}$ For the act declared that Her Majesty's jurisdiction over the open seas adjoining Her dominions not only extended but also "has always extended" over the marginal seas as far as was necessary for the security of Her Majesty's dominions. In the Alabama Claims case, legislation also had to be called into play, for the agreement as to the "Three Rules" of the Treaty of Washington was legislation by the two interested Nations as to that particular case. There was this difference between the two cases, that in the former the legislation was resorted to as a result of the decision, as a means of nullifying it for the future, as well as declaring it wrong as to the past; while in the latter case the legislation was a prerequisite so as to clarify the Law of Neutrality upon which the American and the

55 John Bassett Moore, International Law Digest, Washington, I 906, Volume I., page 7 I4. 
British Governments were not in accord, in order that the Alabama Claims case might be tried before the International Court that sat at Geneva. In both cases, the one tried by a Municipal Court as well as the one tried by an International Tribunal, legislation was necessary.

As Professor John Bassett Moore has so well said, ${ }^{56}$ the legislation agreed upon in the Treaty of Washington by the United States and Great Britain, that is, the Three Rules, which were to be applicable in the Alabama Claims case, did not touch the judicial character of the decision given by the Geneva Tribunal, but affected only the question "whether the award must be accepted as an exposition of contemporaneous International Law-just as we may have a question whether the judgment of one of our Municipal Courts in obedience to a statute is to be regarded as an exposition of the Common Law; and in determining this we are dealing not with the judicial or non-judicial character of the deliverance in the remotest degree, but with the question whether the statute was declaratory of the Common Law."

The essential difference between International Tribunals of Arbitration such as the Geneva Court of $1871-72$ and the Paris Court of 1893 from Munici-

${ }^{56}$ In a letter of October 3 Ist, I 914 , to the present writer. 
pal Tribunals such as the Supreme Court of the United States is that the former are temporary in their existence and constituted to judge a particular case or a series of somewhat similar or analogous cases, while the latter are continuous in their existence, exercise a pre-existing jurisdiction to which all individuals are subject nolens volens, and sit upon all sorts and kinds of cases that may be brought to their bar. It may be, perhaps, that in time, out of such temporary Courts as those that sat and judged at Geneva and Paris between the North American Republic and the British Empire, and the more recently constituted Courts set up $a d$ hoc at the capital of Holland according to the conventions of The Hague Peace Conferences, a Supreme Court of the Nations, always in being, may be evolved to judge legal cases arising between Nations. ${ }^{57}$ But before an attempt is made to establish such a Tribunal to judge always between the members of the family of Nations, it would seem wise that the temporary individual Tribunals set up at The Hague to judge each a designated case or series of similar cases should be changed to the end that

${ }^{57}$ Thomas Willing Balch: Différends juridiques et politiques dans les rapports des Nations, Revue Générale de Droit International Public, Paris, 1914, page 181. 
the judges of such temporary Courts may be strengthened in the judicial habit to the exclusion of reconciling the political desires of the contending Nations.

To insure so far as possible that in the future the decisions given by the International Courts set up ad hoc at The Hague shall base their decisions upon judicial grounds and avoid even a tinge of political compromise creeping in, three things could be resorted to. First, in the agreement or compromis referring a case to one of The Hague International Courts, it could be specifically provided that the decision, as Professor Lassa Oppenheim has suggested, should be based upon legal grounds. Second, the second Hague Convention of 1907 could be amended, so that all the judges in the International Courts provided for under The Hague Conventions should be not only men learned in the Law, but in addition should not be diplomatists by training. Third, in accordance with the motion made at the Second Hague Peace Conference by Mr. Scott of the United States and supported by Professor de Martens of Russia, Doctor Lammasch of Austria, and several other delegates, the individuals appointed by their respective governments to the panel from whom the judges for each of The Hague International Courts should be chosen to try a particular case, must not 
be permitted to appear in any international case as advocates or agents, but only as judges..$^{5 s}$

In addition, it would be well if the publicists of the world criticised favorably or adversely, as the facts, the arguments, and the decision in each case might appeal to them, the judgment of each International Court and even of each individual judge sitting in those Courts, and point out when and in how far each court or individual judge failed to judge according to the Law and sought to base his decision upon a compromise so as not to displease either party. But the criticism of an advocate who had taken part in a case should always be taken cum grano salis. In that manner, the future fame of the individual international jurists sitting in any of The Hague Courts set up ad hoc would rest in a measure in the hands of the men who write and comment upon the Law between Nations. In that way not only a strong incentive for future fame would be available to induce the judges of The Hague International Courts to judge according to the Law between Nations, but also their actual every day

${ }^{58}$ Deuxième Conférence Internationale de la Paix: Acles et Documents, The Hague Impriemrie Nationale, 1907, Vol. II., p. 753. Première Commission, Première souscommission, Comité d'Examen C. Huitième séance, 9, Seplembre 1907; p. 767; Comité d'Examen A. Dıx-septième séance, pages 587-589. 
standing as jurists would be enhanced or lowered accordingly as they decided as international judges or as amiable reconcilers or mediators.

By thus amending the manner of forming The Hague International Courts named ad hoc to try each a single case or a series of similar cases, the judicial character of those International Tribunals of Arbitration would be strengthened; and they could be looked to for the dispensation of justice in the future between Nations as truly as in the past the High Court of Admiralty of England in Lord Stowell's day, or the Supreme Court of the United States or the International Tribunals that sat respectively in the Alabama Claims and the Bering Sea Fur Seal Fisheries cases, handed down judicial decisions based on the principles of the Law and the ideas of justice.

May I3th, I9I5.

PhILAdELPHIA. 
I N D EX. 
, 


\section{N D EX.}

PAGE

Aimable, compositeur.......................... 35, 70

Alabama Claims.................... I, 2, 20, 32, 63-66, 70

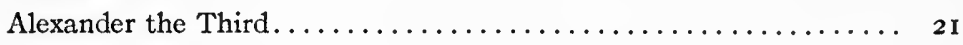

American Civil War....................... 52, 54

Anglo-American boundary case................. 24, 26

Anglo-Venezuelan boundary case . . . . . . . . . . . . 26

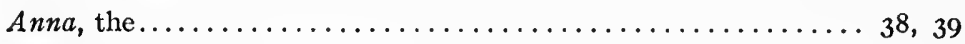

Arbiter......................... 3-5, 7-9, 12

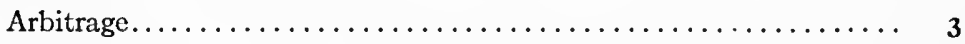

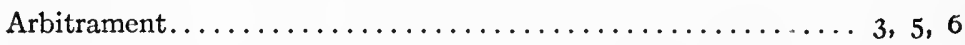

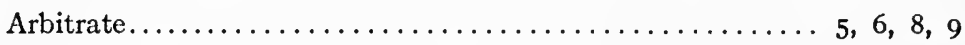

Arbitration................. 5 9, 12, 13, 20, 21, 31, 32

"Arbitration" as a term of International Law............

Arbitration, International. $\ldots \ldots \ldots \ldots \ldots \ldots$ I, 24, 26, 30, 33, 34, 70

Arbitration, International Courts of.......... 23, 25, 27, 29, 30,

$31,54,58,63,64,66,69,70$

Arbitration, Municipal.................. 2, 33

Arbitrator......... 3, 4, 5, 7, 8, 9, II, I2, I3, I5-21, 24, 26, 28

Arbitrator, International. ................ 23, 34, 35

Bering Sea Fur Seal Fisheries case........ I, 2, 23, 25, 63, 64, 70

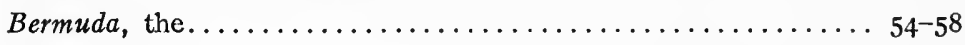

Bouvier, John.......................... 10 2

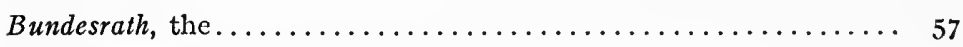

Bynkershoek, Cornelius van................... 39

Cannon shot limit of the territorial sea........... $36,37,40$

Chase, Chief Justice.................... 55-57

Cockburn, Chief Justice.................... 43, 44

Coleridge, Chief Justice...................... 42 
PAGE

Continuous voyages.................. 52, 54, 57, 59

Courts, International................... 28

Courts, Municipal.......2, 23, 33-35, 46, 50, 53, 54, 58, 63, 64, 66

England................. 2, 24, 26, 36, 37, 40-42, 52, 67

English lexicographers.......................... 2

France..................... 2I, 42

Franco-Dutch Guiana frontier case................ 2 I

Fuller, Chief Justice........................ 47-49

Fulton, Thomas Wemyes....................... 36

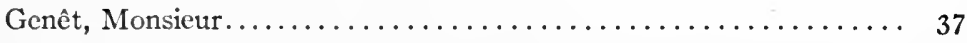

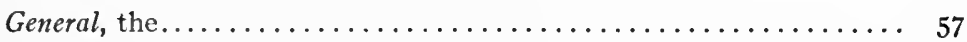

Geneva Tribunal...................... 2, 20, 66, 67

Gray, Justice....................... I4, 47, 48

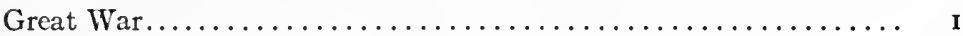

Hague Peace Conferences, The............. 29, 3I, 67, 68

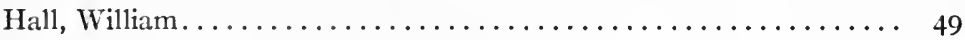

Harlan, Justice......................... 47

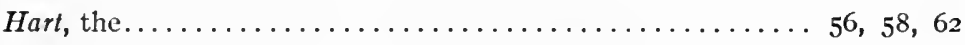

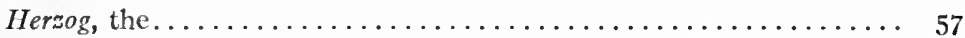

High Court of Admiralty of England.......... I4, 37, 40, 70

Institut de Droit International................ 2I, 23 International Law....... I, 2, I3, I4, 19, 20, 22, 23, 26, 27, 30, 3I, $36,39-4 \mathrm{I}, 43,44,47-49,52,66,69$

James the First of England..................... 36

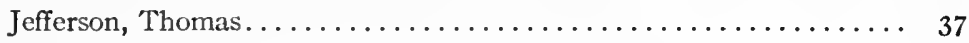

Johnson, Samuel...........................

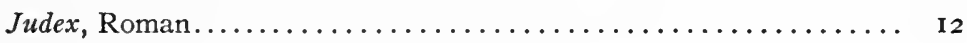

Judge.................. 4, 17, 21, 22, 34, 35, 53, 70 
Klüber, $\mathrm{J} . \mathrm{B} \ldots \ldots \ldots \ldots \ldots \ldots \ldots \ldots \ldots \ldots \ldots \ldots \ldots \ldots \ldots$

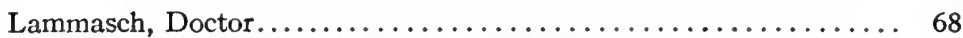

Law between Nations. See International Law.

Law of Nature....................... 15, 17

Legal cases.......................... 28, 67

Maria, the....................... 14, 20

Marine league......................... 36-41, 44-46, 65

Martens, Fedor de......................... 29, 68

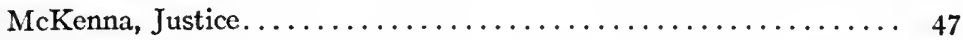

McKinley, President.......................... 47

Mediate.......................... 8, 8-ı

Mediation............... 7, 8, 10, I 1, 26, 27, 31, 32

Mediator................. 7, 8, 10, 18, 22, 26-28, 70

Moore, John Bassett..................... 3I, 65, 66

Municipal Law...................... 2, 13, 17, 23, 31

Netherlands, the.................... 21, 36, 42, 67

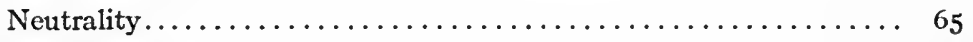

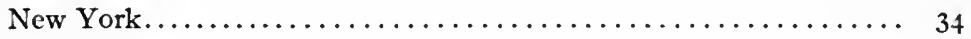

North American Confederation, r $78 \mathbf{r}-\mathbf{r} 789 \ldots \ldots \ldots \ldots \ldots \ldots \ldots \ldots$

Oppenheim, Lassa............................. 68

Paris International Tribunal, $1893 \ldots \ldots \ldots \ldots \ldots \ldots 2,25,66,67$

Paquete Habana, the .................... I4, 46, 53, 63, 64

Paxson, Justice.................... 5 I

Pennsylvania........................... 54, 51

Peterhoff, the....................... 58, 60-63

Philipps, Edward...........................

Political cases.......................... 28, 67

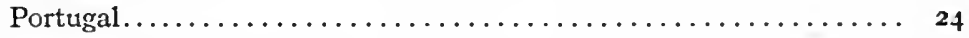

Praetor, Roman............................ 12

Puffendorf, Samuel..................... 15-18 
PAGE

Queen vs. Keyn...................... 40-43, 53, 63-65

Rawle, Francis........................ 12

Renault, Louis...........................23-26

Revue de Droit International et de Législation Comparée.......... 2 I

Rerue Générale de Droit International Public.............. 25

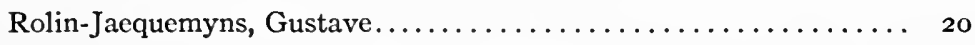

Russia............................. 29, 30

Sanderson vs. The Pennsylvania Coal Company........... 50, 53 Scott, Sir William. See Lord Stowell.

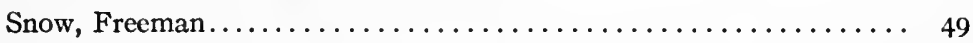

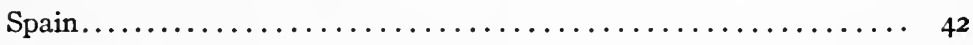

Springbok, the $\ldots \ldots \ldots \ldots \ldots \ldots \ldots \ldots \ldots \ldots \ldots \ldots \ldots \ldots 5^{8-60,6} 63$

State, two meanings of the word in American history....... 33,34

Stowell, Lord..................... I4, 20, 37-40, 49, 52

Three Rules, the, of the Treaty of Washington.......... 65,66

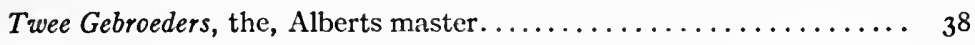

Twee Gebroeders, the, Northolt masters............... 38

United States................ 26, 27, 34, 54, 55, 65, 67

United States Supreme Court...... I4, 46, 47, 52, 57-59, 62, 67, 70

Vanderbilt, the .................. 6 I

Vattel, Emerich de.................... 14, 18

Washington, Treaty of ......................... 65

Webster, Noah............................... $7-9$

Westlake, John............................ 26-29

Worcester, Joseph E...................... 





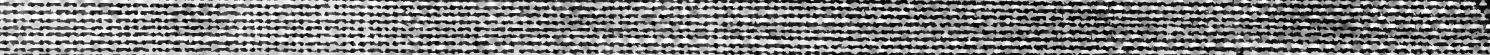

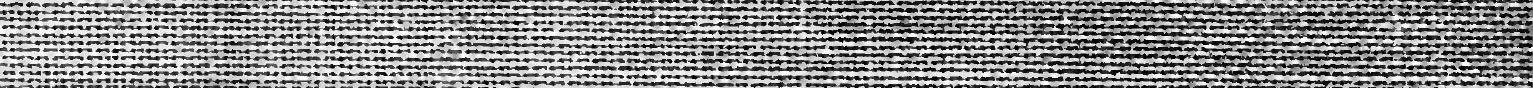

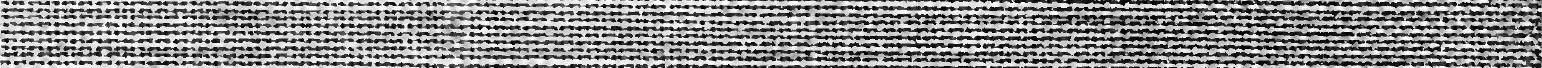
Par

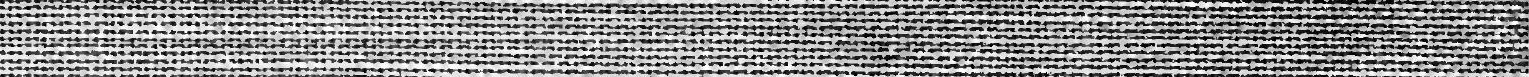
IVI

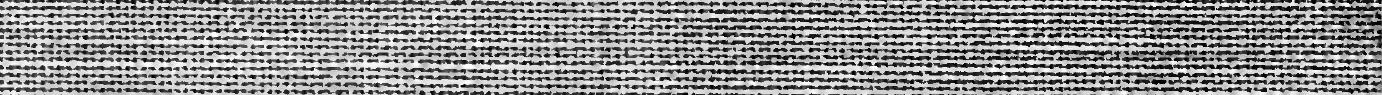
W

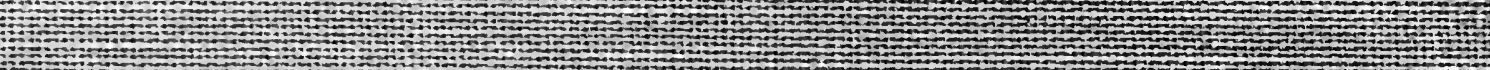

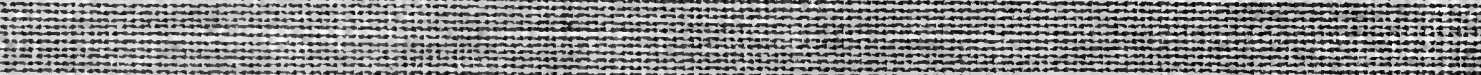
MP Nov,

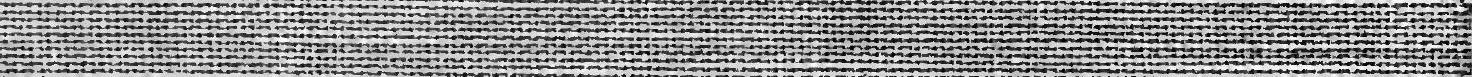

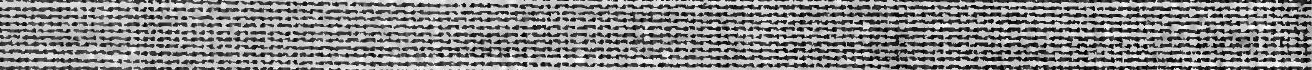

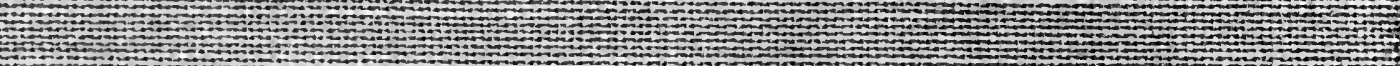

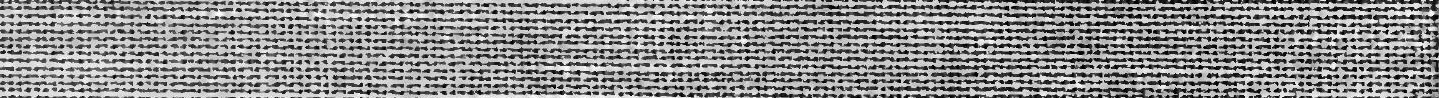

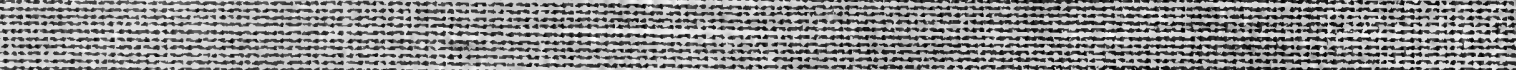

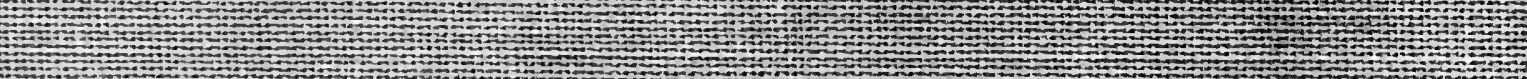

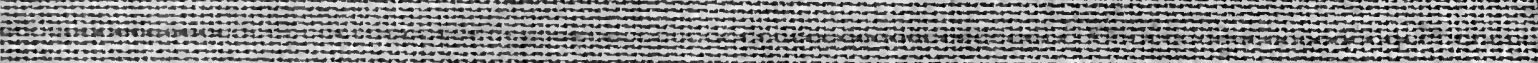

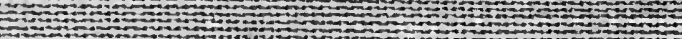

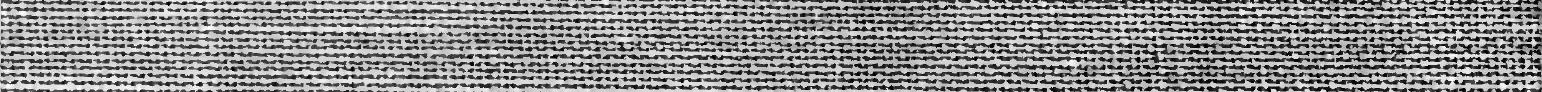
Nov

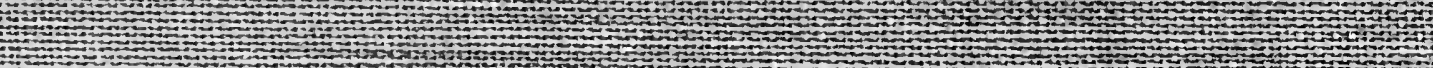
Tov,

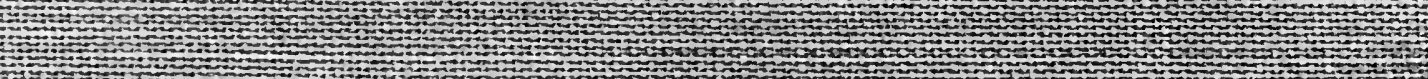

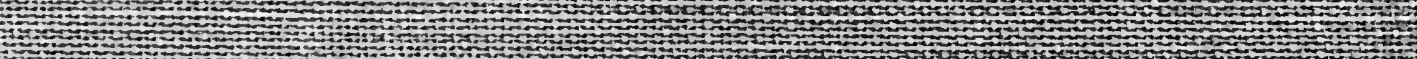

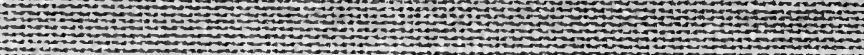
U.

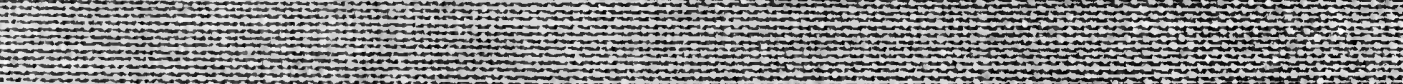
(1) F T.

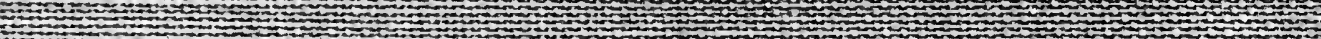

